\title{
The Effect of Logistics Salience on Logistical Capabilities and Firm Performances
}

\author{
Muhammad Furqan Rahim, Muhammad Asim, and Salman Manzoor
}

\begin{abstract}
The purpose of the study is to evaluate the effect of logistics salience on logistics capabilities and performance. The two selected capabilities in the study are service differentiation and innovation. much of the literature has focused on the development of logistics through being customer focused, managing supply chain, integration of processes, measurement and exchanging information therefore, attention shall also be provided on some other and less talked about logistical capabilities which includes innovation and differentiation. The study used survey method for data collection and analysis. The sample size of the study is $\mathbf{1 5 0}$ regression and correlation techniques were applied on the data using SPSS. It was obtained from the results that logistics salience has a positive impact on logistic capabilities and performance. Furthermore, the study also found that logistics innovativeness and service differentiation goes hand in hand and are highly correlated.
\end{abstract}

Keywords - Logistical capabilities; logistics salience; service differentiation; supply chain.

\section{INTRODUCTION}

In the contemporary hypercompetitive markets, firms faces two major issues, the first one is to utilize resources in a manner that can help in creating leverage and developing competitive edge in the market (Esper, Fugate \& DavisSramek, 2007), while the second major issue is to develop an integrated network of supply chain management under the constantly changing environment for long-term sustainability (Hsu, Chen, Chang, \& Chao, 2010). Thus, excellence in logistics and excellent management of supply chain has proven to be a competitive advantage for many firms (Mentzer \& Williams, 2001). Logistics now is not viewed as a source of cost saving center but is also embraced by firms as a border part of supply chain process used for enhancing the product or service offerings and developing a competitive success among competitors (Yazdanparast, Manuj \& Swartz, 2010). Furthermore, logistics is by many scholars is also considered as a resourceful area that supports the integration of and sometime develops strategic moves for the firms (Ho, \& Chang, 2015).

Therefore, the immense focus on the logistical capabilities has developed a need in firms to create sustainable logistical capabilities that can match their resources and can be integrated with their strategy (Esper, Fugate \& Davis-Sramek, 2007). The two ways through which companies develop edge using logistics are cost leadership methods and differentiation strategy. Effective logistic management help companies in cost-leadership through employing efficiency i.e. reduction of cost and capital; and differentiation is obtained through effectiveness in customer service segments (Yazdanparast, Manuj \& Swartz, 2010).

It is also stated that leveraged logistical competences of a firm provides it a strong competitive position in the market, since the capabilities adopted by a logistics leveraged company is based on its infrastructure, which often becomes difficult to copy for the competitors (Mentzer \& Williams, 2001). Logistical capabilities have been vastly studied and reviewed by the researchers. The table 1, below has illustrated some of the mostly common logistical capabilities which are "customer focused capabilities", "supply chain management capabilities", "integration capabilities", "measurement capabilities" and "information exchange capabilities” (Esper, Fugate \& Davis-Sramek, 2007).

Although the aforementioned capabilities have been largely discussed in literature and it has also been proven that these capabilities help companies in developing a competitive advantage, however, it is equally important for companies to sustain this competitive advantage (Parola, Satta \& Panayides, 2015). This can only be done by developing strong barriers through which it becomes difficult for competitors to imitate logistical capabilities. Continuous and flexible changes in the logistics system can be done thorough effective investments for better improvements, bringing innovation in process and through differentiation (Ralston, Grawe, \& Daugherty, 2013).

As stated before much of the literature has focused on the development of logistics through being customer focused, managing supply chain, integration of processes, measurement and exchanging information as shown in table 1 , attention shall also be provided on some other and less

Published on February 07, 2020.

Muhamad Furqan Rahim, Karachi University Business School,

University of Karachi, Pakistan.

(email: Furqan rah@hotmail.com)

Muhammad Asim, Karachi University Business School,

University of Karachi, Pakistan.

(email: masimku@hotmail.com)

*Salman Manzoor, Education and Literacy Department Government of Sindh, Pakistan.

(email: salmankubs@gmail.com) 
talked about logistical capabilities which includes innovation and differentiation. Therefore, the purpose of the current study is to examine the impact of logistics salience (Karagöz \& Akgün, 2015). Therefore, using the model developed by Ralston, Grawe, \& Daugherty (2013), this study has investigated the effect of logistics salience on two capabilities of a firm which are: logistics innovativeness and service differentiation in logistics.

\begin{tabular}{|c|c|c|}
\hline Capability & Description & Cites \\
\hline $\begin{array}{l}\text { Customer } \\
\text { Focus } \\
\text { Capability }\end{array}$ & $\begin{array}{l}\text { Provides product or service differentiation and } \\
\text { service enhancement for continuous } \\
\text { distinctiveness for customers by targeting a } \\
\text { given customer base and meeting or exceeding } \\
\text { their expectations by providing unique, value- } \\
\text { added activities. }\end{array}$ & $\begin{array}{l}\text { Zhao, Dröge, and Stank } \\
\text { 2001; Morash, Dröge, and } \\
\text { Vickery 1996; Stank and } \\
\text { Lackey, Jr. 1997; Lynch, } \\
\text { Keller and Ozment, 2000; } \\
\text { Mentzer, Min, and Bobbitt } \\
\text { 2004; Bowersox, Closs, } \\
\text { and Stank 1999 }\end{array}$ \\
\hline $\begin{array}{l}\text { Supply- } \\
\text { Management } \\
\text { Capability }\end{array}$ & $\begin{array}{l}\text { Involves 1) total cost minimization to minimize } \\
\text { total system costs so that cross-functional cost } \\
\text { tradeoffs are explicitly considered, 2) effective } \\
\text { management of time to eliminate wasted capital } \\
\text { and inventory, 3) response to demand } \\
\text { fluctuations with less distortion of the order } \\
\text { cycle process, and 4) use of resources to enable } \\
\text { postponement speculation, modularization, and } \\
\text { standardization. }\end{array}$ & $\begin{array}{l}\text { Morash, Dröge, and } \\
\text { Vickery 1996; Daugherty } \\
\text { and Pittman 1995; Lowson } \\
\text { 2003; McGinnis and Kohn } \\
\text { 1993; Mentzer, Min, and } \\
\text { Zacharia 2000; Murphy } \\
\text { and Farris 1993. }\end{array}$ \\
\hline $\begin{array}{l}\text { Integration } \\
\text { Capability }\end{array}$ & $\begin{array}{l}\text { A state that exists among internal organizational } \\
\text { elements that are necessary to achieve unity of } \\
\text { effort to meet organizational goals. Includes } \\
\text { internal component (communication aspects } \\
\text { associated with interdepartmental activities the } \\
\text { willingness of departments to work together), } \\
\text { and an external component (two or more firms } \\
\text { voluntarily agree to integrate human, financial, } \\
\text { and/or technical resources in an effort to create } \\
\text { a new, more efficient, effective or relevant } \\
\text { business model). }\end{array}$ & $\begin{array}{l}\text { Daugherty, Stank, and } \\
\text { Ellinger 1998; Stank, } \\
\text { Davis and Fugate 2005; } \\
\text { Kahn and Mentzer 1996; } \\
\text { Bowersox, Closs, and } \\
\text { Stank 2003. }\end{array}$ \\
\hline $\begin{array}{l}\text { Measurement } \\
\text { Capability }\end{array}$ & $\begin{array}{l}\text { Refers to the degree to which a firm monitors } \\
\text { internal and external operations. Aligned with } \\
\text { strategy to make accurate, detailed, relevant, } \\
\text { and timely information accessible to managers } \\
\text { for strategic planning and daily decision making } \\
\text { and enables the translation of business } \\
\text { objectives into measurement specific } \\
\text { operational and financial targets for elements in } \\
\text { the supply chain }\end{array}$ & $\begin{array}{l}\text { Global Logistics Research } \\
\text { Team at Michigan State } \\
\text { University 1995; Fawcett, } \\
\text { Smith, and Cooper 1997; } \\
\text { Gilmour 1999; Holmberg } \\
\text { 2000; Bowersox, Closs, } \\
\text { and Stank 2000. }\end{array}$ \\
\hline $\begin{array}{l}\text { Information } \\
\text { Exchange } \\
\text { Capabilities }\end{array}$ & $\begin{array}{l}\text { Acquires, analyzes, stores, and distributes } \\
\text { tactical and strategic information both inside } \\
\text { and outside the firm through the application of } \\
\text { hardware, software and networks to enhance } \\
\text { information flow and facilitate decisions. }\end{array}$ & $\begin{array}{l}\text { Zhao et al. 2001; Mentzer, } \\
\text { Min, and Bobbitt 2004; } \\
\text { Closs, Goldsby, and } \\
\text { Clinton 1997. }\end{array}$ \\
\hline
\end{tabular}

Fig 1: Logistic Capabilities (Source: Esper, Fugate \& Davis-Sramek, 2007)

Innovativeness is defined as the approval, expectations and the support given by the management to the employees for trying new and improved ways of work, whereas, logistical innovativeness is also defined as permission and support provided to employees in logistics department for carrying out activities using new techniques or implementing new ideas and improved methods (Ralston, Grawe, \& Daugherty, 2013). On the other hand, differentiation is defined as developing product or service that is unique as well as valuable to the customers. In the similar way, logistics differentiation is the process of producing and delivering new, unique as well as valuable logistics solutions to the customers (Lee \& Song, 2015).

Therefore, by adding the constructs of innovation and service differentiation capabilities this research paper will add to knowledge specifically related to supply chain and logistics management. Furthermore, using the limitations highlighted by (Lee \& Song, 2010), this research paper has examined the effect of operational level firm performances instead of firm-wide performance.

It has also been noted that organizational departments that provide firms with extra resources in-turn receives more firm resources such as power or money etc. However, this phenomenon is particularly true for logistics department of a firm because logistics has the ability to extent the boundaries of a firm (Clifford, Defee, \& Fugate, 2010). Therefore, logistics department shall be considered as a core function rather than a supporting function in a company. The department of logistics is a key instrument that integrates and coordinates supply chain activities which in-turns develops corporate and customer value (Ralston, Grawe, \& Daugherty, 2013). By considering logistics as a valuable resource for a firm, the study has raised two questions which have guided in the overall completion of this study:

1) What is the effect of logistics salience on the two capabilities (innovativeness and service differentiation) of a firm?

2) What is the relationship between firm performance and logistics capabilities (innovativeness and service differentiation)?

\section{LITERATURE REVIEW}

In most of the companies the logistic department is kept unappreciated, moreover, the logistic department is also seen as a cost center rather than a strategic resource. The phenomenon is supported by various research findings (Mohamad, Udin, \& Sharif, 2018). The study conducted by Hwang \& Kim (2019) stated that most of the traditional activities in the logistics department were non-value adding. On the contrary, the research conducted by Gruchmann \& Seuring (2018) showed that logistics provides a competitive advantage to the company. However, companies need to recognize and leverage its activities in order to utilize and create maximum value from logistics. Pellathy, In, Mollenkopf, \& Stank (2018) stated that logistics department need to be salient in order to become profitable for a firm. Logistics salience is also said to be the extension of firm's shared culture.

In the current study two capabilities of logistics are assessed, which are innovativeness and service differentiation. Dai, Che, Lim, \& Shou (2019) defined innovativeness as the tendency of a firm to engage in the process of developing new ideas through creative thinking or experimentation. Innovativeness and its impact has been assessed in different industries, such as Fernando \& Chukai (2018) tested the effect of innovation in hospital industry and founds that it helps in fostering innovation. In the similar way, Obeng \& Mkhize (2017) tested the effect of innovativeness in IT companies and concluded that innovation at department level tends to effect companies more than overall innovation done at managerial levels. Chen (2018) founds a positive link between innovation and competitive advantage. In the same manner, Wallenburg, Johne, Cichosz, Goldsby, \& Knemeyer (2019) studied logistic innovation and established that logistic innovation helps in finding out smart solutions for logistical problems 
the study also finds out that one of the other drivers of logistic innovation is logistics salience.

The second capability being studied in the research is differentiation; it is defined as the process of setting up distinguishable features in a product or service through which the product or service can be made unique as compared to the competitor. However, it is stated that differentiation is effective only if it is able to provide additional benefit to the customer or is able to reduce cost for the customers (Chu, Feng, \& Lai, 2018). It is also stated that differentiation in terms of product price seems to less effective in markets of standardization; therefore, service differentiation in such cases can help a company in standing out (Maata \& Ombui, 2018).

Service differentiation is the ability to provide customizes services to the customers for meeting their individual needs. Service differentiation can be achieved by providing services that are unique in terms (Kasemsap, 2017). On the other hand, it is also stated that differentiation is also challenging for non-service company. As in nonservice companies it is hard to provide products that cannot be matched or are hard to imitate, therefore, distinction can be made through services (García-Dastugue \& Eroglu, 2019).

Service differentiation in logistics is the process of providing unique services to the customers. Through service differentiation customers are able to assess the performance of the company besides physical product. Therefore, service differentiation can be made by devising unique methods of delivering product to the customer (Thakur \& Jasrai, 2018).

Logistics differentiation can only be achieved when companies start to value logistics department. If logistics is valued companies will find ways to exploit logistics department and obtain a competitive advantage (AnningDorson, Hinson, Amidu, \& Nyamekye, 2018). Other than this, the study also aims at testing the relationship logistics differentiation and innovativeness. Different studies have used RBV (resource based view) technique in order to determine the relationship between logistics capabilities.

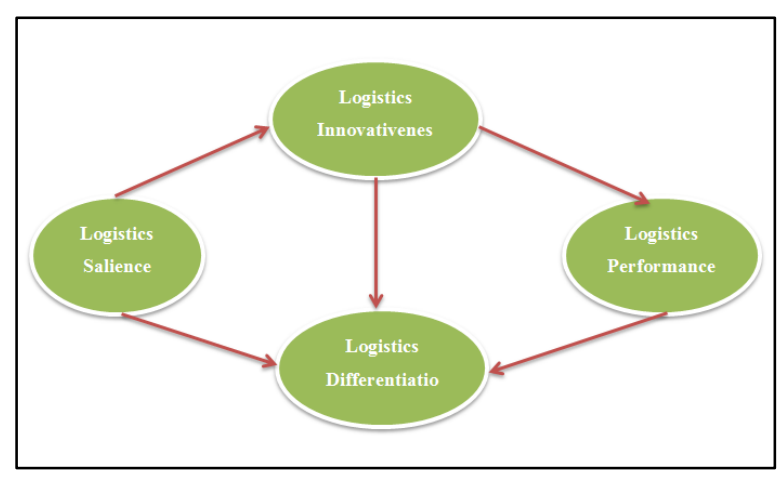

Fig 2: Theoretical Framework of Research

As per the theory of RBV performance and capabilities are two key tenants. The link between the two has also been discussed and examined by various previous researchers. However, in the current study, logistic capabilities and its effect on logistics performance has been examined. Esper,
Fugate \& Davis-Sramek (2007) stated that most of the previous studies have focused on the effect of capabilities to performance, however, the vice versa i.e. the impact on performance responsible for the development of capabilities were neglected. Ferraz \& de Melo Santos (2016) was of the view that unique logistic capabilities can improve the overall logistics performance. Anning-Dorson, Hinson, Amidu \& Nyamekye (2018) found that capabilities within the logistics department are the key factor in developing customized solutions for the customers. Wang, Yuen, Wong, \& Teo (2018) added that logistics capabilities shall be reviewed by firms in order to ensure that they are providing maximum benefits to the customers.

\section{A. Research Hypothesis}

Based on the previous literatures the study has devised the following literature:

H1: Logistics salience has a positive effect on logistics innovativeness

H2: Logistics salience has a positive effect on logistics service differentiation

H3: Logistics innovativeness has a positive relationship with logistics service differentiation

H4: Logistics innovativeness has a positive relationship with logistics performance.

H5: Logistics service differentiation has a positive relationship with logistics performance.

\section{METHODS}

In order to test the hypothesis designed in the study, quantitative and primary data has been selected. The study has implied deductive research approach as it aims to test the significance and implacability of already proposed theories. As it was observed from previous literature that most of the studies regarding capabilities and performance of supply chain management was done in developed countries like UK, USA, Germany, France and Australia, therefore, in the current study companies in the Pakistani market has been selected in order fulfil this gap as well due to ease to access to the market.

The research instrument used in the study is close-ended questionnaire; this questionnaire has been adopted from various previous studies conducted on different context (See Appendix). The close-ended questionnaire was based on five point lickert-scales and had statements for all the four variables in the study.

The data was collected using online tools such as survey monkey, through this website the link for the questionnaire was sent to different employees working in supply chain companies or in the logistic department. About 200 questionnaires were distributed in the study, however, some of them were rejected due to incomplete answers therefore, sample size of the study is 150 .

The collected data was assessed using SPSS. Using SPSS, the study tested reliability of the instrument, after getting a satisfactory response descriptive statistics were 
carried out, furthermore, the test for correlation was done to check the strength of the relationship between variable. Finally, in order to test the devised hypothesis regression analysis was conducted.

\section{FINDINGS}

This section of the study has shown the results obtained from survey. The section has shown test for reliability, frequency analysis, correlation analysis and regression analysis.

\section{A. Test for Reliability}

TABLE I: RELIABILITY ANALYSIS

\begin{tabular}{|c|c|}
\hline Reliability Statistics \\
\hline Cronbach's Alpha & N of Items \\
\hline .928 & 21 \\
\hline
\end{tabular}

Test for reliability indicates whether the respondents of the research were able to understand research instrument and respond accordingly. Reliability is measured through Cronbach's Alpha value. The alpha value greater than .60 indicates that the data is highly reliable (Hinton \& McMurray, 2017). In the current study the value of Cronbach's Alpha has appeared to be .928 this indicates that the instrument used in the study is highly reliable.

\section{B. Frequency Analysis}

Frequency analysis is divided into two parts, in the first part demographic analysis has been carried out; this section reflects upon the age, gender, and level of experience possessed by the research respondents. While in the second section descriptive statistics have been analysed, this analysis has indicated the responses gained against each variable.

\section{Demographic Analysis}

Gender

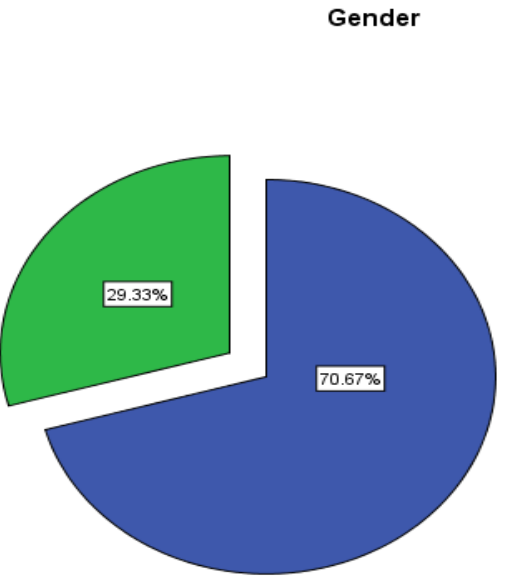

Fig 3 (a) : Demographic Analysis

The graph above has depicted the percentage of male and female participants included in the study. It can be seen that the percentage of male participants were $70.6 \%$ while female participants were $29.3 \%$.

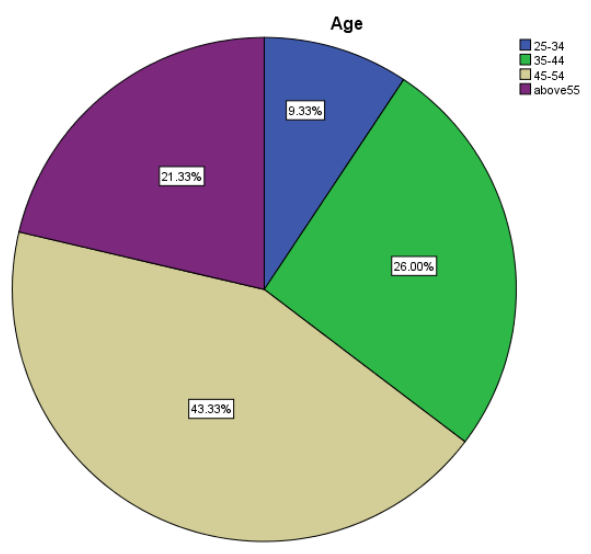

Fig 3 (b): Demographic Analysis

The respondents were divided into 4 brackets. The age brackets include 25-34, 35-44, 45-54 and above 55. The results indicated that about $43 \%$ of the research respondents belong to 45-55 years of age; this shows that most of the research responses have been collected from people having vast experience and knowledge about the market. Likewise, $26 \%$ of the respondents belong to the age group of $35-44$ years. The graph has also depicted that $21 \%$ of the respondents were above the age 55 years, while $9 \%$ of the respondents belongs to the age group of 25-34.

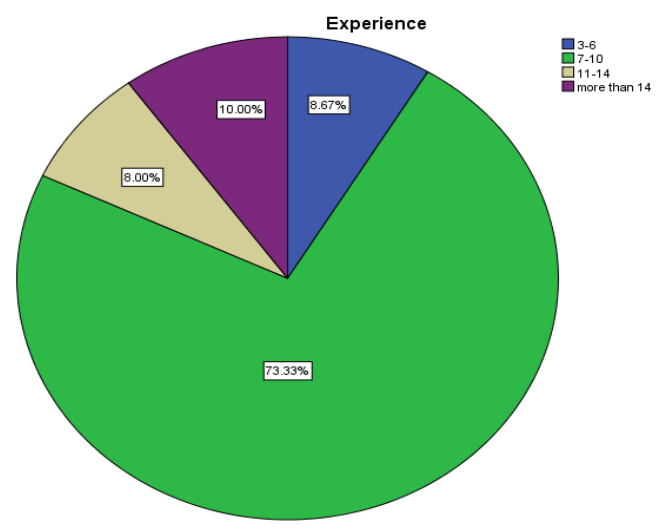

Fig 3 (c) : Demographic Analysis

The third demographic character that has been included in the study was experience. The experience was divided into 4 categories which are 3-6 years, 7-10 years, 11-14 years and more than 14 years. The graph above has depicted that $73.33 \%$ of the respondents belong to the age group of $7-10$ years' experience level.

\section{Descriptive Analysis}

\section{Logistics Salience Effect}

About seven statements were provided to the respondents regarding logistics salience effect. The first statement was about recognition of logistic department as important within the firm. It can be seen in chart 1, appendix 2 that $48 \%$ of the people have agreed that logistics system in their firm is considered as highly important, whereas, only about $11 \%$ of the respondents have responded negatively. He second 
statement was about the visibility of the logistics system, the graph 2 in appendix 2 have depicted that $46 \%$ of the people agree that their company has a visible logistic system. In the same manner, graph 3 showed that $42 \%$ of the respondents believe that their logistic department has access to top management of the company. While graph 4 in appendix 2 shows that most of the people being surveyed are of the view that logistic department provides cost advantage to the company, $53 \%$ of the people being surveyed also believe that logistic department contributes towards providing service advantage. However, when asked about provision of competitive advantage through logistic department, mix responses were obtained, as about $20 \%$ of the respondents have disagreed with the statement believing that logistic department do not contribute in providing competitive edge to the company, however, $28.6 \%$ of the respondents believes that there is a visible contribution of logistic department towards development of competitive edge for the company (see graph 6, appendix 2). On the other hand, about $42 \%$ of the respondents also believe that logistics department contributes in making the firm highly profitable.

\section{Logistics Innovativeness}

About five statements were asked from the respondents regarding logistics innovativeness. The first statement asked whether the employees in the logistics department are open and responsive towards change. It was observed from the responses (see graph 8, appendix 2) that 33\% of the respondents have agreed with the statement, while $22 \%$ have disagreed with it. In the next statement regarding innovativeness it was assessed weather the employees take time in developing new ideas, and it was observed that $52 \%$ of the respondents have responded positively. From graph number 9, it can also be viewed that majority of the participants believe that employees in the logistic department cooperates developing and in applying new ideas. About $47 \%$ of the participants are of the view that employees in logistic department provides and share resources that are required for the implementation of new idea, while $51 \%$ of the employees also believe that they are provided with practical support for the implementation of new idea in the logistic department (graph 12, appendix 2).

\section{Logistics Service Differentiation}

The first statement was weather the logistic services were highly differentiated or not, in response about $52.67 \%$ of the people believe that their services are highly differentiated. In the same manner, about $42 \%$ of the respondents also think that the logistic service provided by the company is customized in order to meet the needs of the business partners (Graph 14 and 15, appendix 2). In the same manner, $33 \%$ of the responses have shown that logistic services provided by their company provide services that are not offered by other companies.

\section{Logistics Performance}

About $52 \%$ of the respondents believe that their logistic department has the ability to reduce cost through efficiency, technology and economies of scale. In the same manner, more than $57 \%$ of the respondents stated that their logistic department is able to reduce the time between order receipts and customer delivery (graph 17 and 18, appendix 2). In the same manner, graph 19 has shown that the logistic department of the respondents has the ability to meet quoted dates and quantities on consistent basis. Likewise, 52\% of the respondents also believe that their logistic department is up to the expectations of the customers.

\section{Correlation Analysis}

TABLE II CORRELATIONS ANALYSIS

\begin{tabular}{|c|c|c|c|c|c|}
\hline & & LSE & LI & LSD & LP \\
\hline LSE & $\begin{array}{c}\begin{array}{c}\text { Pearson } \\
\text { Correlation }\end{array} \\
\text { Sig. (2-tailed) } \\
\text { N }\end{array}$ & 150 & $\begin{array}{l}.594^{* *} \\
.000 \\
150\end{array}$ & $\begin{array}{l}.663^{* *} \\
.000 \\
150\end{array}$ & $\begin{array}{l}.468^{* *} \\
.000 \\
150\end{array}$ \\
\hline LI & $\begin{array}{c}\begin{array}{c}\text { Pearson } \\
\text { Correlation }\end{array} \\
\text { Sig. (2-tailed) } \\
\text { N }\end{array}$ & $\begin{array}{c}.594^{*} \\
* \\
.000 \\
150\end{array}$ & 150 & $\begin{array}{l}.711^{* *} \\
.000 \\
150\end{array}$ & $\begin{array}{l}.959^{* *} \\
.000 \\
150\end{array}$ \\
\hline LSD & $\begin{array}{c}\begin{array}{c}\text { Pearson } \\
\text { Correlation }\end{array} \\
\text { Sig. (2-tailed) } \\
\text { N }\end{array}$ & $\begin{array}{c}.663^{*} \\
{ }_{*}^{*} \\
.000 \\
150\end{array}$ & $\begin{array}{l}.711^{* *} \\
.000 \\
150\end{array}$ & 150 & $\begin{array}{l}.612^{* *} \\
.000 \\
150\end{array}$ \\
\hline LP & $\begin{array}{c}\text { Pearson } \\
\text { Correlation } \\
\text { Sig. (2-tailed) } \\
\text { N }\end{array}$ & $\begin{array}{l}.468^{*} \\
.000 \\
.00 \\
150\end{array}$ & $\begin{array}{l}.959^{* *} \\
.000 \\
150\end{array}$ & $\begin{array}{l}.612^{* *} \\
.000 \\
150\end{array}$ & 150 \\
\hline
\end{tabular}

**. Correlation is significant at the 0.01 level (2-tailed).

The correlation analysis reveals the relationship between the two variables; it also shows the percentage of change experience by one variable due to other (Oshima \& Dell-Ross, 2016). It can be seen from the table above that changes in logistic salience effect imposes a positive effect on other variables, however, the degree of change experience by other variable is very different. As it can be seen that logistic innovativeness will be affected by .594 units due to change in logistic salience, while logistic service differentiation and logistic performance is effected by .663 and .468 units respectively, the effect has also appeared to be significant since the value of sig has appeared to be less than 0.000 . Consequently, it can also be interpreted from the table above that logistic innovativeness; logistic service differentiation and logistic performance are also positively as well as significantly correlated with each other.

\section{E. Regression Analysis}

Regression analysis shows the exact impact of one variable on the other, while it also tells weather the change is significant or not, the fitness of model and the future trend can also be predicted using regression model (Mohamad, Udin, \& Sharif, 2018).

H1: Logistics salience has a positive effect on logistics innovativeness 
TABLE III (a) : REGRESSION ANALYSIS (H1) MODEL SUMMARYb

\begin{tabular}{|l|c|r|r|r|r|}
\hline Model & $\mathrm{R}$ & $\begin{array}{c}\mathrm{R} \\
\text { Square }\end{array}$ & $\begin{array}{c}\text { Adjusted R } \\
\text { Square }\end{array}$ & $\begin{array}{l}\text { Std. Error of } \\
\text { the Estimate }\end{array}$ & $\begin{array}{l}\text { Durbin- } \\
\text { Watson }\end{array}$ \\
\hline 1 & $.594^{\mathrm{a}}$ & .353 & .348 & .76327 & .833 \\
\hline
\end{tabular}

a. Predictors: (Constant), LSE

b. Dependent Variable: LI

In the first hypothesis, the dependent variable is logistic innovativeness, while the independent variable is logistic salience effect. It can be observed that the value of $\mathrm{R}$ has appeared to be .594 which shows the correlation between them, thus a strong correlation exist between the two variables.

TABLE III (b) REGRESSION ANALYSIS (H1) ANOVA ${ }^{\mathrm{a}}$

\begin{tabular}{|rl|l|r|l|l|l|}
\hline Model & & $\begin{array}{l}\text { Sum of } \\
\text { Squares }\end{array}$ & df & $\begin{array}{l}\text { Mean } \\
\text { Square }\end{array}$ & F & Sig. \\
\hline 1 & $\begin{array}{l}\text { Regressi } \\
\text { on }\end{array}$ & 46.979 & 1 & 46.979 & 80.64 & $.000^{\mathrm{b}}$ \\
& $\begin{array}{l}\text { Residu } \\
\text { al } \\
\text { Total }\end{array}$ & 86.221 & 14 & .583 & & \\
& 133.200 & 14 & & & \\
& & & & & \\
\hline
\end{tabular}

a. Dependent Variable: LI

b. Predictors: (Constant), LSE

ANOVA table reveals model fitness, as the value of sig. is less than 0.05 , therefore, it can be stated the model selected is highly fitted

TABLE III (c ) REGRESSION ANALYSIS (H1) COEFFICIENTS ${ }^{a}$

\begin{tabular}{|c|c|c|c|c|c|}
\hline \multirow[b]{2}{*}{ Model } & \multicolumn{2}{|c|}{$\begin{array}{l}\text { Unstandardized } \\
\text { Coefficients }\end{array}$} & \multirow{2}{*}{$\begin{array}{l}\begin{array}{l}\text { Standardize } \\
\text { d } \\
\text { Coefficients }\end{array} \\
\text { Beta }\end{array}$} & \multirow[b]{2}{*}{$\mathrm{t}$} & \multirow[b]{2}{*}{ Sig. } \\
\hline & B & Std. Error & & & \\
\hline $\begin{array}{l}\text { (Constant } \\
\text { ) }\end{array}$ & .760 & .305 & & 2.492 & .014 \\
\hline LSE & .774 & .086 & .594 & 8.980 & .000 \\
\hline
\end{tabular}

Based on the table of coefficients the following equation of regression has been made:

Logistic Innovativeness $=.760+.774($ logistic Salience)

It can be inferred from the above equation that one unit change in logistic salience will effect logistic innovation by .774 units. However, the equation has also showed that even in the absence of logistic salience the innovativeness will increase on a slower pace i.e. by .760 units. Therefore, it can be stated that the first hypothesis of the study has been accepted and that logistic salience has a positive effect on logistic innovativeness. The study conducted by GarcíaDastugue \& Eroglu (2019) also stated that logistic salience is one the drivers in logistics innovativeness. Fernando \& Chukai (2018) also showed that logistic innovativeness allows the department to come up with unique ideas for the department eventually helps overall company.

H2: Logistics salience has a positive effect on logistics service differentiation

\section{TABLE IV (a) REGRESSION ANALYSIS (H2) MODEL SUMMARY ${ }^{\mathrm{b}}$}

\begin{tabular}{|l|l|l|l|l|l|}
\hline Model & $\mathrm{R}$ & $\begin{array}{l}\mathrm{R} \\
\text { Square }\end{array}$ & $\begin{array}{l}\text { Adjusted R } \\
\text { Square }\end{array}$ & $\begin{array}{l}\text { Std. Error } \\
\text { of the } \\
\text { Estimate }\end{array}$ & $\begin{array}{l}\text { Durbin- } \\
\text { Watson }\end{array}$ \\
\hline 1 & $\begin{array}{r}.663 \\
\mathrm{a}\end{array}$ & .440 & .436 & .57879 & 1.105 \\
\hline
\end{tabular}

a. Predictors: (Constant), LSE

b. Dependent Variable: LSD

It can be observed that logistic salience and logistic service differentiation are positively and strongly correlated with other as the value of $\mathrm{R}$ has appeared to be .663 units.

TABLE IV (b) REGRESSION ANALYSIS (H2) ANOVA ${ }^{a}$

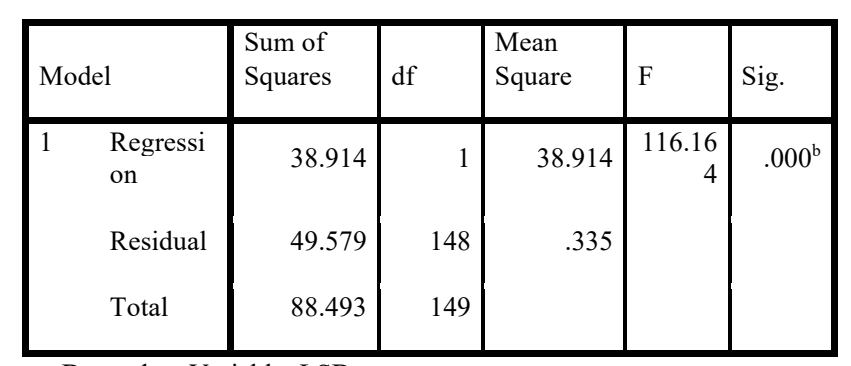

a. Dependent Variable: LSD

b. Predictors: (Constant), LSE

It can be observed that the sig. value has appeared to be .000 , therefore, the model selected for the research is highly fitted and the trends in logistics service differentiation can be predicted using logistic salience effect.

TABLE IV (c) REGRESSION ANALYSIS (H2) COEFFICIENTS ${ }^{a}$

\begin{tabular}{|c|c|c|c|c|c|}
\hline \multirow[b]{2}{*}{ Model } & \multicolumn{2}{|c|}{$\begin{array}{l}\text { Unstandardized } \\
\text { Coefficients }\end{array}$} & \multirow{2}{*}{$\begin{array}{l}\begin{array}{l}\text { Standardize } \\
\mathrm{d} \\
\text { Coefficients }\end{array} \\
\text { Beta }\end{array}$} & \multirow[b]{2}{*}{$\mathrm{t}$} & \multirow[b]{2}{*}{ Sig. } \\
\hline & B & Std. Error & & & \\
\hline $\begin{array}{ll}1 \text { Constant } \\
& )^{\prime}\end{array}$ & .804 & .231 & & 3.477 & .001 \\
\hline LSE & .705 & .065 & .663 & 10.778 & .000 \\
\hline
\end{tabular}

a. Dependent Variable: LSD

The equation of regression for the above table has appeared to be:

Logistic service differentiation $=.804+.705$ (Logistic salience effect) 
Thus, it can be observed that logistic salience has a positive effect on logistic service differentiation. Furthermore, the equation also shows that unit increase in logistic salience will effect service differentiation by .705 units. Thus, the second hypothesis of the study has also been accepted. The result obtained in the study can also be supported by the findings of Pellathy, In, Mollenkopf, \& Stank (2018) the researcher stated that in service industries differentiation can be obtained by providing unique solutions to the customers.

H3: Logistics innovativeness has a positive relationship with logistics service differentiation

TABLE V (a) REGRESSION ANALYSIS (H3) MODEL SUMMARY ${ }^{\mathrm{b}}$

\begin{tabular}{|c|c|c|c|c|c|}
\hline $\begin{array}{l}\text { Mo } \\
\text { del }\end{array}$ & $\mathrm{R}$ & $\begin{array}{l}\text { R } \\
\text { Squar } \\
\text { e }\end{array}$ & $\begin{array}{l}\text { Adjusted } \\
\text { R Square }\end{array}$ & $\begin{array}{l}\text { Std. } \\
\text { Error of } \\
\text { the } \\
\text { Estimate }\end{array}$ & $\begin{array}{l}\text { Durbin- } \\
\text { Watson }\end{array}$ \\
\hline 1 & $.711^{\mathrm{a}}$ & .505 & .502 & .54377 & 1.463 \\
\hline
\end{tabular}

a. Predictors: (Constant), LI

b. Dependent Variable: LSD

It can be seen that logistic service differentiation and logistics innovativeness are strongly as well as positively correlated as the value of correlation between the two has appeared to be .711 .

TABLE V (b) REGRESSION ANALYSIS (H3)ANOVA ${ }^{a}$

\begin{tabular}{|c|c|c|c|c|c|}
\hline Model & $\begin{array}{l}\text { Sum of } \\
\text { Squares }\end{array}$ & $\mathrm{df}$ & $\begin{array}{l}\text { Mean } \\
\text { Square }\end{array}$ & $\mathrm{F}$ & Sig. \\
\hline $\begin{array}{l}1 \text { Regressio } \\
\mathrm{n}\end{array}$ & 44.732 & 1 & 44.732 & $\begin{array}{r}151.28 \\
2\end{array}$ & $.000^{\mathrm{b}}$ \\
\hline Residual & 43.761 & 148 & .296 & & \\
\hline Total & 88.493 & 149 & & & \\
\hline
\end{tabular}

a. Dependent Variable: LSD

b. Predictors: (Constant), LI

Logistic innovativeness is a corrected predictor of logistic service differentiation as the sig value is also less than .005 .

TABLE V (c) REGRESSION ANALYSIS (H3) COEFFICIENTS ${ }^{a}$

\begin{tabular}{|c|c|c|c|c|c|}
\hline \multirow[b]{2}{*}{ Model } & \multicolumn{2}{|c|}{$\begin{array}{l}\text { Unstandardized } \\
\text { Coefficients }\end{array}$} & \multirow{2}{*}{$\begin{array}{l}\text { Standardiz } \\
\text { ed } \\
\text { Coefficien } \\
\text { ts } \\
\text { Beta }\end{array}$} & \multirow[b]{2}{*}{$\mathrm{t}$} & \multirow[b]{2}{*}{ Sig. } \\
\hline & B & Std. Error & & & \\
\hline $\begin{array}{ll}1 & \text { (Consta } \\
& \text { nt) }\end{array}$ & 1.250 & .168 & & 7.437 & .000 \\
\hline LI & .580 & .047 & .711 & 12.300 & .000 \\
\hline
\end{tabular}

a. Dependent Variable: LSD

The equation for regression is as follows:
Logistics service differentiation $=1.205+.580($ logistics innovativeness)

It can be predicted from the above equation that a unit increase in logistic innovativeness will effect service differentiation by .580 units. Obeng \& Mkhize (2017) also founds a positive link between innovation and differentiation. It is also stated that logistic innovativeness help employees in coming up with unique ideas. Chen (2018) stated that logistic differentiation also boost performance of the company.

H4: Logistics innovativeness has a positive relationship with logistics performance.

TABLE VI (a) REGRESSION ANALYSIS (H4) MODEL SUMMARY

\begin{tabular}{|l|r|r|l|r|l|}
\hline $\begin{array}{l}\text { Mod } \\
\text { el }\end{array}$ & $\mathrm{R}$ & $\begin{array}{l}\mathrm{R} \\
\text { Square }\end{array}$ & $\begin{array}{l}\text { Adjusted R } \\
\text { Square }\end{array}$ & $\begin{array}{l}\text { Std. Error of } \\
\text { the Estimate }\end{array}$ & $\begin{array}{l}\text { Durbin- } \\
\text { Watson }\end{array}$ \\
\hline 1 & $.959^{\mathrm{a}}$ & .919 & .919 & .29913 & 2.279 \\
\hline
\end{tabular}

a. Predictors: (Constant), LI

b. Dependent Variable: LP

b. Dependent Variable: LP

The relationship between logistic innovativeness and logistics performance has appeared to be .959 , which shows that both the variables are very strongly correlated and moves in almost similar direction.

TABLE VI (b) REGRESSION ANALYSIS (H4) ANOVA ${ }^{\mathrm{a}}$

\begin{tabular}{|c|c|c|c|c|c|c|}
\hline \multicolumn{2}{|c|}{ Model } & $\begin{array}{l}\text { Sum of } \\
\text { Squares }\end{array}$ & df & $\begin{array}{l}\text { Mean } \\
\text { Square }\end{array}$ & $\mathrm{F}$ & Sig. \\
\hline \multirow{2}{*}{\multicolumn{2}{|c|}{$\begin{array}{ll}1 \quad \begin{array}{l}\text { Regress } \\
\text { ion }\end{array} \\
\\
\\
\text { Residua } \\
1\end{array}$}} & 150.870 & 1 & 150.870 & $\begin{array}{r}1686.0 \\
52\end{array}$ & \multirow[t]{3}{*}{$.000^{\mathrm{b}}$} \\
\hline & & 13.243 & 148 & \multirow[t]{2}{*}{.089} & & \\
\hline & Total & 164.113 & 149 & & & \\
\hline \multicolumn{7}{|c|}{ a. Dependent Variable: LP } \\
\hline
\end{tabular}

As the value of sig has appeared to be less than 0.05 therefore, it can be stated that the selected model is highly fitted for the study.

TABLE VI (c) REGRESSION ANALYSIS (H4) COEFFICIENTS ${ }^{a}$

\begin{tabular}{|c|c|c|c|c|c|}
\hline \multirow[b]{2}{*}{ Model } & \multicolumn{2}{|c|}{$\begin{array}{l}\text { Unstandardized } \\
\text { Coefficients }\end{array}$} & \multirow{2}{*}{$\begin{array}{l}\text { Standar } \\
\text { dized } \\
\text { Coeffici } \\
\text { ents } \\
\text { Beta }\end{array}$} & \multirow[b]{2}{*}{$\mathrm{t}$} & \multirow[b]{2}{*}{ Sig. } \\
\hline & B & Std. Error & & & \\
\hline $\begin{array}{ll}1 & \text { (Consta } \\
& \text { nt) }\end{array}$ & -.148 & .092 & & -1.598 & .112 \\
\hline LI & 1.064 & .026 & .959 & $\begin{array}{r}41.06 \\
2\end{array}$ & .000 \\
\hline
\end{tabular}

a. Dependent Variable: LP

The equation of regression is as follows: 
Logistics performance $=-.148+1.064$ (logistics innovativeness)

It can be inferred from the above equation that a unit increase in innovativeness will improve logistics performance by 1.064 units i.e. by more than $100 \%$. On the other hand, the equation also shows that in the absence of logistics innovativeness the logistics performance will deteriorate by .148units as constant value appears to be negative. Wallenburg, Johne, Cichosz, Goldsby, \& Knemeyer (2019) stated that logistics innovativeness provides external benefits to the company in terms of creating value for the company.

H5: Logistics service differentiation has a positive relationship with logistics performance.

TABLE VII(a) REGRESSION ANALYSIS (H5) MODEL SUMMARY ${ }^{\mathrm{b}}$

\begin{tabular}{|l|r|r|r|r|l|}
\hline $\begin{array}{l}\text { Mod } \\
\text { el }\end{array}$ & R & $\begin{array}{l}\text { R } \\
\text { Square }\end{array}$ & $\begin{array}{l}\text { Adjusted R } \\
\text { Square }\end{array}$ & $\begin{array}{l}\text { Std. Error of } \\
\text { the Estimate }\end{array}$ & $\begin{array}{l}\text { Durbin- } \\
\text { Watson }\end{array}$ \\
\hline 1 & $.612^{\mathrm{a}}$ & .375 & .370 & .83273 & 1.097 \\
\hline
\end{tabular}

a. Predictors: (Constant), LSD

b. Dependent Variable: LP

The correlation between logistics service differentiation and logistics performance has appeared to be .612 , therefore, it can be stated that the two variables are highly correlated.

TABLE VII(b) REGRESSION ANALYSIS (H5) ANOVA ${ }^{a}$

\begin{tabular}{|r|r|r|l|l|l|}
\hline Model & $\begin{array}{l}\text { Sum of } \\
\text { Squares }\end{array}$ & df & \multicolumn{1}{l|}{$\begin{array}{l}\text { Mean } \\
\text { Square }\end{array}$} & F & Sig. \\
\hline $\begin{array}{l}1 \\
\text { Regressio } \\
\text { Residual }\end{array}$ & 61.485 & 1 & 61.485 & 88.668 & $.000^{\mathrm{b}}$ \\
& 102.628 & 148 & .693 & & \\
& 164.113 & 149 & & & \\
\hline
\end{tabular}

a. Dependent Variable: LP

b. Predictors: (Constant), LSD

The criteria used for measuring logistics performance using logistics service differentiation has appeared to be accurate since the value of sig has appeared to be less than 0.05 .

TABLE VII (c) REGRESSION ANALYSIS (H5) COEFFICIENTS ${ }^{\mathrm{a}}$

\begin{tabular}{|c|c|c|c|c|c|}
\hline \multirow[b]{2}{*}{ Model } & \multicolumn{2}{|c|}{$\begin{array}{l}\text { Unstandardized } \\
\text { Coefficients }\end{array}$} & \multirow{2}{*}{$\begin{array}{l}\begin{array}{l}\text { Standardi } \\
\text { zed } \\
\text { Coefficie } \\
\text { nts }\end{array} \\
\text { Beta }\end{array}$} & \multirow[b]{2}{*}{$\mathrm{t}$} & \multirow[b]{2}{*}{ Sig. } \\
\hline & B & Error & & & \\
\hline $\begin{array}{ll}1 & \text { (Consta } \\
& \text { nt) }\end{array}$ & .810 & .295 & & 2.745 & .007 \\
\hline LSD & .834 & .089 & .612 & 9.416 & .000 \\
\hline
\end{tabular}

a. Dependent Variable: LP
The following equation of regression has been devised using the above table:

Logistics performance $=.810+.834($ logistics service differentiation)

It can be stated that logistics service differentiation effects logistics performance by .834 units, while in the absence of differentiated services the performance will decrease to .810 therefore, differentiation in logistics seems to be highly important for the companies. The findings gained from Thakur \& Jasrai (2018) showed that logistic salience in firms develops a willingness to search for alternate options and capabilities. These capabilities further develops benefits for the customers as well as for the company, therefore, the overall performance of a firm improves.

\section{DISCUSSION}

Dai, Che, Lim, \& Shou (2019) were of the view that logistics in future can be force for determining success and failures of companies. Although logistics has earned respect and its rightful position in companies, however, it is not true for all the company. It has been observed that logistics has not become essential for top managers in most of the companies due to which logistic department have failed to deliver to the customers. From review of previous literature the study has also concluded that logistics managers have lacked in marketing the advantages of logistics department to the top management.

However, from the findings of the current study companies can evaluate that having the knowledge of what companies can attain from logistics; companies can develop capabilities of improving overall logistics performance. The results of the study also showed that logistics salience is just the starting point and that an overall success cycle can be developed through logics salience. The findings gained from the study has also highlighted that if logistics department is seen as salient for a firm then the level of influence of logistics on the firm will increase. Once logistics importance has been recognized companies are likely to provide more resources to the logistics department. Similarly the research conducted by Hwang \& Kim (2019) also showed that having useful resources in the logistic department not only helps in improving productivity and performance but it also elevates the morale of workers in the department. Gruchmann \& Seuring (2018) also added that logistics if given proper resources can help firm in developing competitive advantage. It was also developed from the findings of the research that logistic innovativeness work as promoter for service differentiation. As innovative environment in the logistics department develops and promotes a need to come up with innovative ideas. Firms also urge its employees to find better ways in response to the competitor's offerings, thus, improving the overall performance.

\section{CONCLUSION}

The purpose of the current study was to revisit logistic salience and its effect on logistic capabilities and performance. Out of several logistic capabilities the study selected two new and most significant capabilities which are 
innovativeness and service differentiation. The results obtained from the study found that logistic salience has a positive impact on both the capabilities as well as on the performance of the firm. Furthermore, it was also developed that both logistics innovativeness and logistics service differentiation are highly interlinked with each other.

\section{REFERENCES}

Anning-Dorson, T., Hinson, R. E., Amidu, M., \& Nyamekye, M. B. (2018) Enhancing service firm performance through customer involvement capability and innovativeness. Management Research Review, 41(11), 1271-1289.

Chen, C. J. (2018). Developing a model for supply chain agility and innovativeness to enhance firms' competitive advantage. Management Decision.

Chu, Z., Feng, B., \& Lai, F. (2018). Logistics service innovation by third party logistics providers in China: Aligning guanxi and organizational structure. Transportation Research Part E: Logistics and Transportation Review, 118, 291-307.

Clifford Defee, C., \& Fugate, B. S. (2010). Changing perspective of capabilities in the dynamic supply chain era. The International Journal of Logistics Management, 21(2), 180-206.

Dai, J., Che, W., Lim, J. J., \& Shou, Y. (2019). Service innovation of cold chain logistics service providers: A multiple-case study in China. Industrial Marketing Management.

Esper, T. L., Fugate, B. S., \& Davis-Sramek, B. (2007). Logistics learning capability: sustaining the competitive advantage gained through logistics leverage. Journal of Business Logistics, 28(2), 57-82.

Fernando, Y., \& Chukai, C. (2018). Value co-creation, goods and service tax (GST) impacts on sustainable logistic performance. Research in Transportation Business \& Management, 28, 92-102.

Ferraz, I. N., \& de Melo Santos, N. (2016). The relationship between service innovation and performance: a bibliometric analysis and research agenda proposal. RAI Revista de Administração e Inovação, 13(4), 251260.

García-Dastugue, S., \& Eroglu, C. (2019). Operating Performance Effects of Service Quality and Environmental Sustainability Capabilities in Logistics. Journal of Supply Chain Management, 55(3), 68-87.

Gruchmann, T., \& Seuring, S. (2018). Explaining logistics social responsibility from a dynamic capabilities perspective. The International Journal of Logistics Management, 29(4), 1255-1278.

Hinton, P. R., \& McMurray, I. (2017). Presenting Your Data with SPSS Explained. Routledge.

Ho, L. H., \& Chang, P. Y. (2015). INNOVATION CAPABILITIES, SERVICE CAPABILITIES AND CORPORATE PERFORMANCE IN LOGISTICS SERVICES. International Journal of Organizational Innovation, 7(3).

Hsu, C. L., Chen, M. C., Chang, K. C., \& Chao, C. M. (2010). Applying loss aversion to investigate service quality in logistics: A moderating effect of service convenience. International Journal of Operations \& Production Management, 30(5), 508-525.

Hwang, T., \& Kim, S. T. (2019). Balancing in-house and outsourced logistics services: effects on supply chain agility and firm performance. Service Business, 13(3), 531-556.

Karagöz, I. B., \& Akgün, A. E. (2015). The roles of it capability and organizational culture on logistics capability and firm performance. Journal of Business Studies Quarterly, 7(2), 23.

Kasemsap, K. (2017). The roles of logistics service providers and supply chain integration in global supply chain. In Global intermediation and logistics service providers (pp. 265-285). IGI Global.
Lee, E. S., \& Song, D. W. (2010). Knowledge management for maritime logistics value: discussing conceptual issues. Marit. Pol. Mgmt., 37(6), 563-583.

Lee, E. S., \& Song, D. W. (2015). The effect of shipping knowledge and absorptive capacity on organizational innovation and logistics value. The International Journal of Logistics Management, 26(2), 218237.

Maata, S. W., \& Ombui, K. (2018). Role of Third-Party Logistics Services on Supply Chain Performance In Distribution Sector In Kenya: A Case Of Bollore Transport \& Logistics Kenya Limited. International Journal of Supply Chain Management, 3(2), 22-43.

Mentzer, J. T., \& Williams, L. R. (2001). The role of logistics leverage in marketing strategy. Journal of Marketing Channels, 8(3-4), 29-47.

Mohamad, M. F., Udin, Z. M., \& Sharif, K. I. (2018, September). Innovative, marketing and supportive capability impacts towards logistics performance. In AIP Conference Proceedings (Vol. 2016, No. 1, p. 020093). AIP Publishing.

Obeng, A. Y., \& Mkhize, P. L. (2017). An exploratory analysis of employees and customers' responses in determining the technological innovativeness of banks. The Electronic Journal of Information Systems in Developing Countries, 80(1), 1-23.

Oshima, T. C., \& Dell-Ross, T. (2016). All possible regressions using IBM SPSS: A practitioner's guide to Automatic linear modeling.

Parola, F., Satta, G., \& Panayides, P. M. (2015). Corporate strategies and profitability of maritime logistics firms. Maritime Economics \& Logistics, 17(1), 52-78.

Pellathy, D. A., In, J., Mollenkopf, D. A., \& Stank, T. P. (2018). Middlerange theorizing on logistics customer service. International Journal of Physical Distribution \& Logistics Management, 48(1), 2-18.

Ralston, P. M., Grawe, S. J., \& Daugherty, P. J. (2013). Logistics salience impact on logistics capabilities and performance. The International Journal of Logistics Management, 24(2), 136-152.

Thakur, A., \& Jasrai, L. (2018). A Logit Model to Predict Innovativeness among Mobile Telecom Service Users. Global Business Review, 19(3_suppl), S54-S71.

Wallenburg, C. M., Johne, D., Cichosz, M., Goldsby, T. J., \& Knemeyer, A. M. (2019). Alignment mechanisms for supplier-initiated innovation: Results from the logistics service industry. Journal of Purchasing and Supply Management, 25(5), 100575.

Wang, X., Yuen, K. F., Wong, Y. D., \& Teo, C. C. (2018). E-consumer adoption of innovative last-mile logistics services: A comparison of behavioural models. Total Quality Management \& Business Excellence, $1-27$.

Yazdanparast, A., Manuj, I., \& Swartz, S. M. (2010). Co-creating logistics value: a service-dominant logic perspective. The International Journal of Logistics Management, 21(3), 375-403.

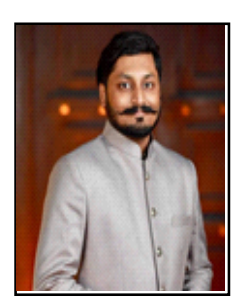

Muhammad Furqan Rahim is from Karachi Pakistan born on 22-07-1993. MSc. in Biochemistry from university of Karachi Pakistan in 2016. Present final year student of MBA (Supply Chain management) from Karachi University Business School, University of Karachi Pakistan.

$\mathrm{He}$ is working as SUPPLY CHAIN EXECUTIVE at LaGuardia Petroleum Private Limited Karachi Pakistan. 
APPENDIX
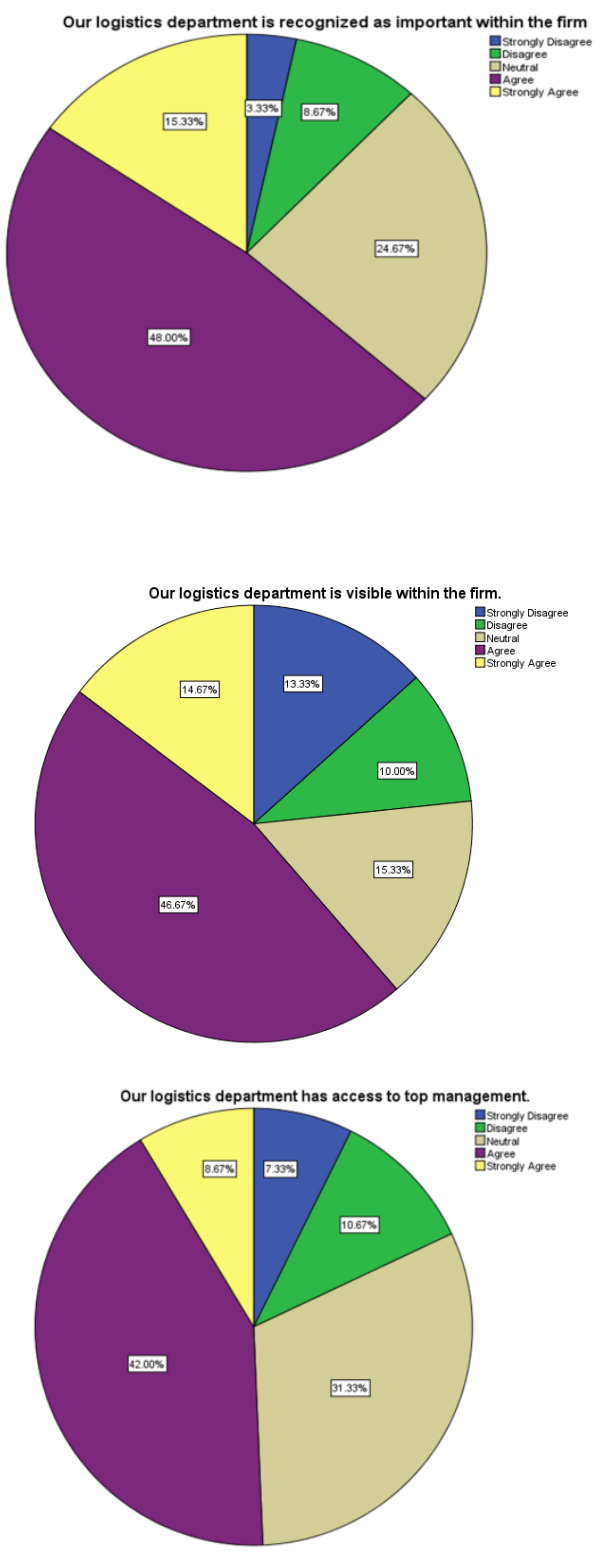

Our logistics department contributes in terms of providing a cost advantage.

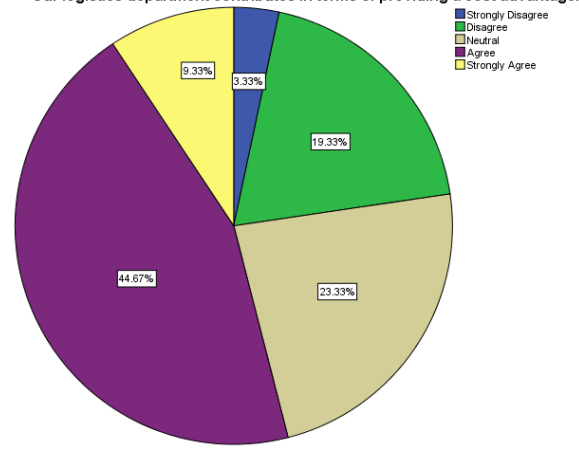

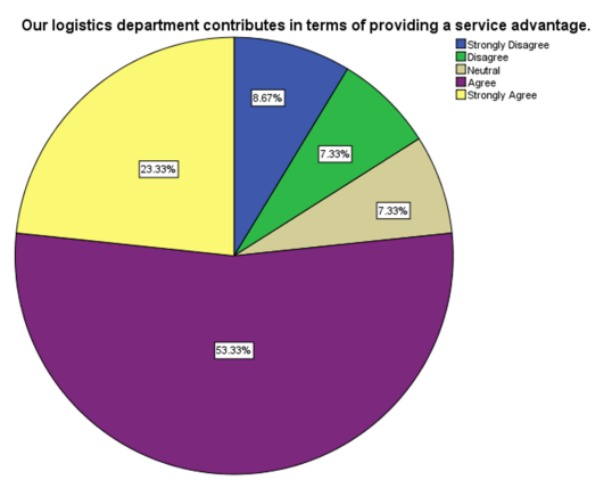

Our logistics department contributes in terms of providing a competitive

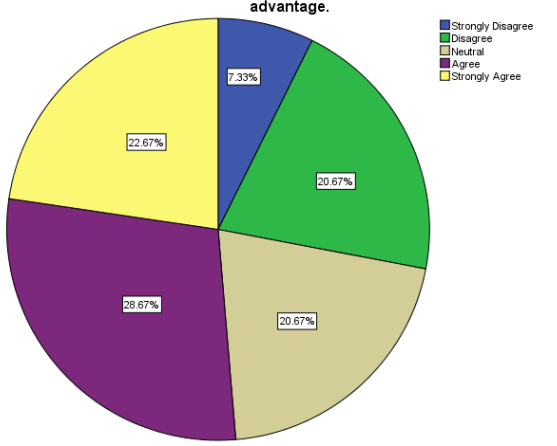

Our logistics department contributes in terms of providing a profitability
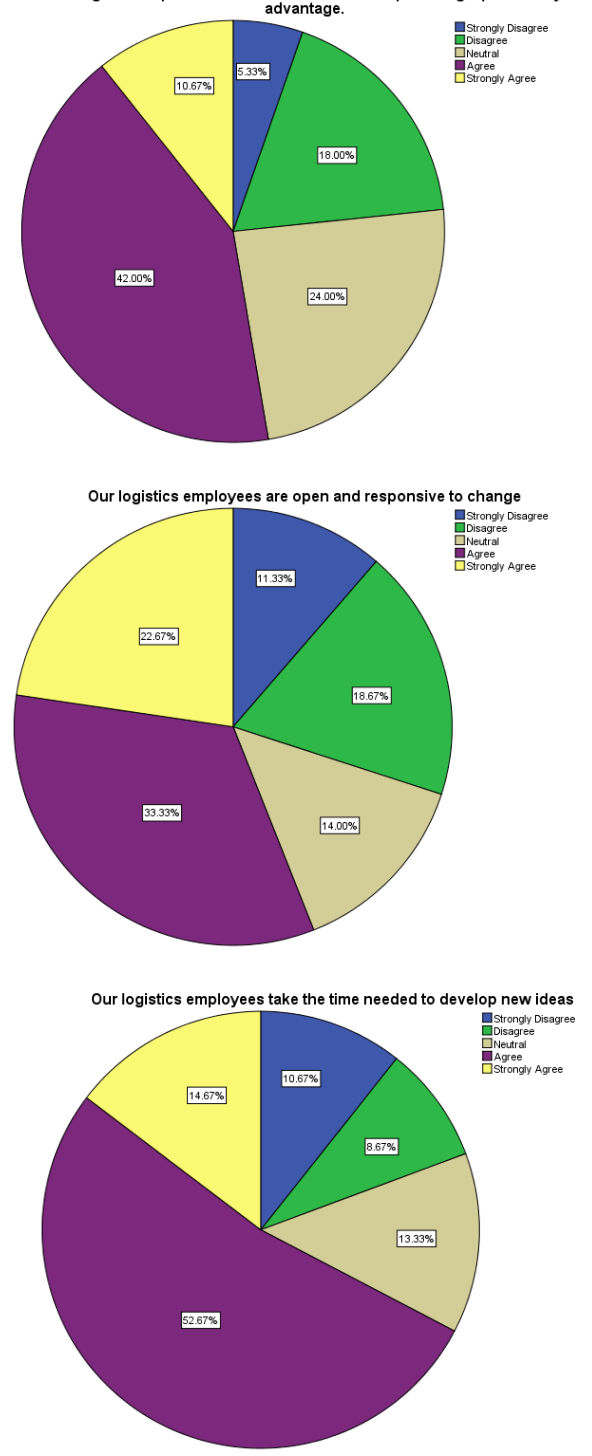

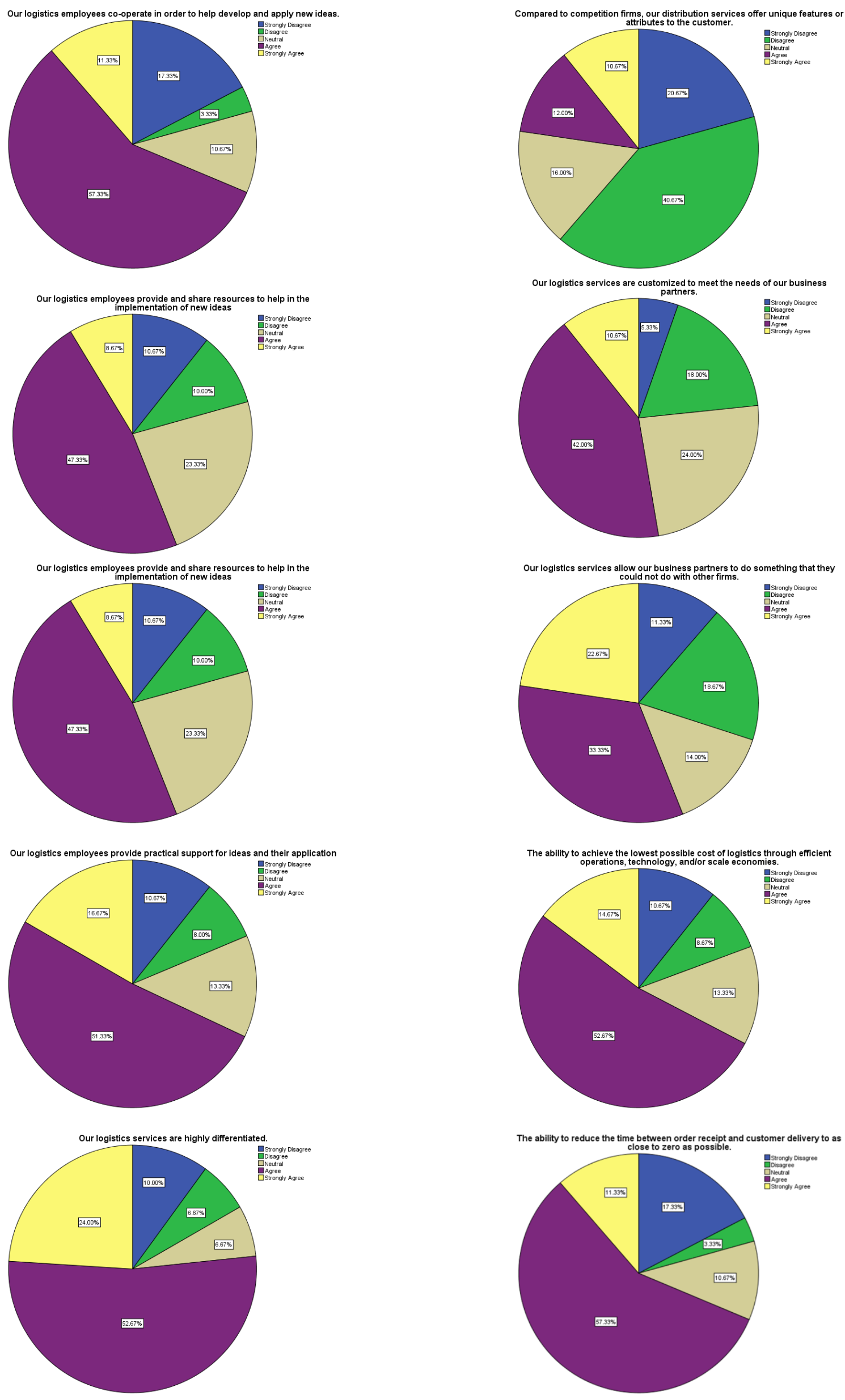


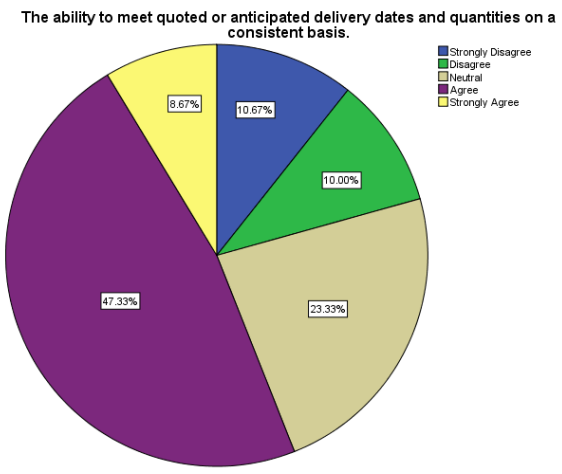

The ability to provide desired quantities on a consistent basis.

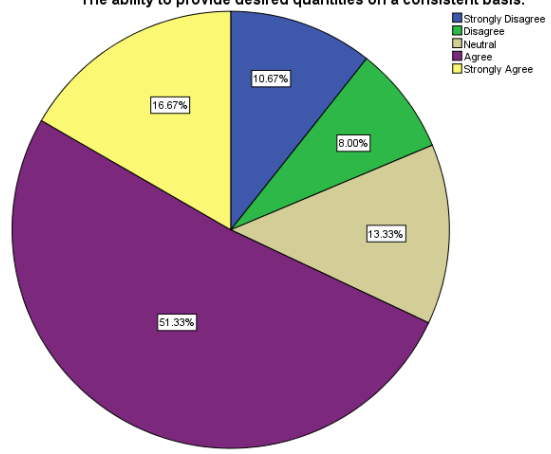

The extent to which perceived logistics performance matches customer

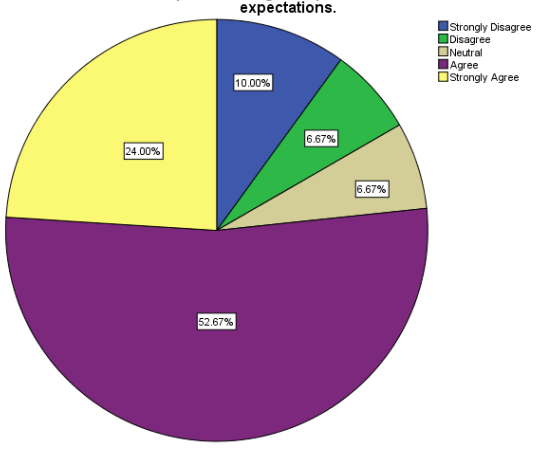


EJBMR, European Journal of Business and Management Research

Vol. 5, No. 1, February 2020 
EJBMR, European Journal of Business and Management Research

Vol. 5, No. 1, February 2020 